\title{
The Effect of Cooperative Learning Models Giving Question and Getting Answer (GQGA) On Students' Learning Outcomes In SD Inpres BTN IKIP I Makassar City
}

\author{
Ahmad Syawaluddin ${ }^{1}$, Andi Makkasau ${ }^{2}$, Nevi Karisma ${ }^{3}$ \\ \{syawaluddin@unm.ac.id ${ }^{1}$ \} \\ ${ }^{1,2,3}$ PGSD FIP UNM, Indonesia
}

\begin{abstract}
The purposes of this research are; (1) to find out the application of Giving Question and Getting Answer (GQGA) cooperative learning model in science learning; (2) to find out the description of the students' learning outcomes in science subject; (3) to determine the effect of GQGA toward the learning outcomes of fourth grade students. The research design used is Quasi Experimental Design. The population in this research was all fourth grade students using simple random sampling. Data were collected using a research instrument in the form of multiple choice tests / questions consisting of 25 items. The instrument used was validated by experts and field validation. The data analysis technique used was Independent Sample T-Test with the help of IBM SPSS Statistics Version 20. The results showed that the application of GQGA for each meeting had increased and was in the very effective category. The descriptive analysis result shows that students' learning outcomes before treatment are in the moderate category while after being treated using GQGA are in the high category with the average (mean) obtained is 86.1538 . The probability value of the results of the hypothesis test is 0.001 . The data proves that $0.001<0.05$ so that there is a significant influence of the application of GQGA to science learning outcomes of students in grade IV SD Inpres BTN IKIP I Makassar.
\end{abstract}

Keywords: Giving Question Getting Answer, Learning Outcomes

\section{Introduction}

Education is an important issue not only for individuals, but also for every nation, thus it needs to get more attention from society, especially from the government. Law No. 20 year 2003 concerning National Education System article 3 states that national education functions to develop the ability of the nation's character and dignified civilization in the context of educating the life of the nation, aiming at developing the potential of students to become human beings who believe in and have faith toward God Almighty, healthy, knowledgeable, capable, creative, independent, and be a democratic and responsible citizen.

Every educational institution must have a curriculum that serves as a guideline to achieve educational goals. Education at the elementary level, namely elementary school (SD), junior high school (SMP), vocational and specialty, has a predetermined curriculum. The curriculum applied at the elementary level has been contained in the Law of the Republic of Indonesia No. 20 year 2003 concerning the National Education System article 37 paragraph (1) that the curriculum for primary and secondary education must contain (a) religious education; (b) 
citizenship education; (c) languages; (d) mathematics; (e) natural science; (f) social science; (g) arts and culture; (h) physical education and sports; (i) skills / vocational, and (j) local content.

Each subject set in the curriculum has its own role. One curriculum that must be applied is Natural Sciences (IPA). Through science subjects, students are expected not only to gain knowledge about science but students are also able to recognize natural phenomena that are developing and can react according to their experiences and findings. In other words, after studying science students are able to recognize, respond, think, and behave critically in a critical way in appreciating science and technology. In addition, natural science subjects obtained in elementary schools will later be a provision for students to study Natural Sciences to a higher level of education. Science is a subject that instills and develops scientific knowledge, skills, attitudes, and values in students. Science education is the science of natural phenomena as outlined in the form of facts, concepts, principles, and laws that have been verified and gone through a series of activities in the scientific method (Hisbullah and Selvi 2018).

At the initial observation, on January 10-17 in 2019, researchers obtained data on Minimum Mastery Criteria in natural science subjects in SD Inpres BTN IKIP I was 75. The average learning outcomes of grade IV science students of SD Inpres BTN IKIP I Makassar were 77. In the learning process, to teach science material that is theoretical, the implementation of the learning process was still teacher-centered. In the teacher-centered learning process, the teacher dominates the learning activities, while students were not actively involved in the learning process. Based on the results of observations, student learning outcomes caused by two aspects, namely aspects of the teacher and aspects of students. From the teacher aspects of: 1) the teacher did not maximally create a pleasant learning atmosphere; 2) the teacher was not maximally building cooperation between students in the learning process, and 3) the teacher did not maximally provide the opportunity for students to ask questions or answer. As for the aspects of students in the form of: 1) students did not maximally pay attention to the teacher's explanation; 2) students did not maximally work together during the learning process, and 3) students were not brave enough to ask or answer so it is difficult to know students' understanding of the material being taught.

These problems can be overcome by applying a learning model that is suitable with the learning material. However, each learning model has advantages and disadvantages. The teacher must be able to choose suitable learning models that are applied in accordance with the subjects and the material being taught.

There are many learning models that can make it easier for teachers to carry out the main task as teaching staff. One of them is Cooperative Learning. The main objective in applying cooperative learning model is that students can learn in groups with their friends by respecting each other's opinions and giving others the opportunity to express their ideas by expressing their opinions in groups (Isjoni 2012). "Cooperative learning is learning that consciously develops mutually caring interactions between students to avoid offense and misunderstanding that can lead to hostility" (Lecturer Team 2017).

According to Rusman (2017: 294), "cooperative learning is a form of learning by means of students learning and working in small groups collaboratively and heterogeneously." Cooperative learning provides opportunities for students to cooperate with each other with different conditions and background so learning to respect each other (Mariyaningsih and Hidayati 2018).

One learning model that teachers can use in the science learning process is Giving Answer and Getting Answer (GQGA) cooperative learning model. The GQGA learning model is 
designed so that in the learning process students can actively ask questions and express their own thoughts to their friends. If there are students who do not ask questions and do not answer questions, then the student receives punishment which is to make a summary of the learning material that has been learned.

The explanation above is supported by research conducted by Ning Tias Prima Wilinda (2013) on "The Effectiveness of Giving Question and Getting Answer learning model on Natural Resource Learning Outcomes of Class IV Students of State Elementary School 06 Pemarukan Pemalang" which shows that there are differences in student learning outcomes of class IV significant between learning using the Giving Question and Getting Answer learning model with conventional learning.

Based on the statement, the researcher designed a study with the title "The effect of the Giving Question and Getting Answer (GQGA) cooperative learning model on the learning outcomes of Natural Sciences for students in grade IV SD Inpres BTN IKIP I Makassar City."

\section{Research Method}

This study uses a quantitative approach with experimental research type. The type of experimental research used is Quasi Experimental Design. This study uses two variables, namely the independent variable and the dependent variable. The independent variable in this study is the GQGA cooperative learning model $(\mathrm{X})$, while the dependent variable in this study is the science learning outcomes (Y). The research design used in this study is Pretest-Posttest Control Group Design. For more details, research design can be seen in the following table:

Table 2. Results of Validity Test

\begin{tabular}{|c|c|c|c|}
\hline Group (Class) & Pre-Test & Treatment & Post-Test \\
\hline Experimental Group & $\mathrm{O}_{1}$ & $\mathrm{X}$ & $\mathrm{O}_{2}$ \\
Control Group & $\mathrm{O}_{3}$ & - & $\mathrm{O}_{4}$ \\
\hline
\end{tabular}

\footnotetext{
Information:

$\mathrm{O}_{1}$ : pretest (learning outcomes) experimental class

$\mathrm{O}_{2}$ : pretest (learning outcomes) control class

$\mathrm{X}$ : treatment with the GQGA learning model

$\mathrm{O}_{3}$ : posttest (learning outcomes) class experiment

$\mathrm{O}_{4}$ : posttest (learning outcomes) control class

-: use conventional models
}

The population in this study was all grade IV students in SD Inpres BTN IKIP I Makassar $2018 / 2019$ academic year in the even semester. The total population of this study was 60 students. The sample is a portion or representative of the population. The sampling technique used in the study was simple random sampling without taking into account the strata in the population. So that the samples obtained were 52 students. The experimental class is IV B and the control class is IVA.

Data collection techniques used were observation sheets, science learning outcomes tests, and documentation. Before using the instrument, the validity of the research instrument is tested first. The instrument validity in this study used content and field validity. This 
instrument was validated by lecturers who were experts in their fields. For field validation carried out with fifth grade students in SD Inpres IKIP I Makassar. After validation, items used were captured in the following table:

Table 2. Results of Validity Test

\begin{tabular}{|c|c|c|}
\hline \multicolumn{2}{|c|}{ Number of Test Items } & \multirow{2}{*}{ Item Drop } \\
\hline Before Validation & After Validation & 5 \\
\hline 30 & 25 & 5 \\
\hline
\end{tabular}

Observation is a way of collecting data by observing the learning process. Observational actions were taken to determine the feasibility of using GQGA cooperative learning models in science subjects. The aspects observed were learning process activities starting from the beginning to the end of learning. The observed aspects are categorized into the following table:

Table 3. Implementation of the Learning Process

\begin{tabular}{|c|c|}
\hline Score & Category \\
\hline$<20 \%$ & Very Less Effective \\
\hline $21 \%-40 \%$ & Less effective \\
\hline $41 \%-60 \%$ & Moderately effective \\
\hline $61 \%-80 \%$ & Effective \\
\hline $81 \%-100 \%$ & Very effective \\
\hline
\end{tabular}

Data collection procedure begins with learning carried out during 2 meetings. The details of the implementation procedure were as follows: (1) pretest activities were carried out before giving treatment with the aim of knowing students' learning outcomes in science subjects before given treatment in the experimental class or in the control class; (2) the provision of treatment in the form of teaching and learning activities using GQGA cooperative learning model carried out in the experimental class and the control class was given treatment without using GQGA cooperative learning model; (3) giving a posttest to compare students' knowledge after treatment in the control class and the experimental class.

Data analysis techniques used in this study are descriptive statistical analysis and inferential statistical analysis. Descriptive data analysis was carried out to describe the learning outcomes of science students in grade IV through pretest and posttest. Student learning outcomes data include minimum value, maximum value, mean, range, standard deviation, median, and mode. Pretest and posttest data were processed using the IBM SPSS version 20.0 application.

Inferential statistical analysis is used to test research hypotheses using the Independent Sampe T-Test. To test the research hypothesis, a prerequisite analysis test was first carried out, namely the normality and homogeneity tests which were processed using the IBM SPSS version 20.0 application. The operational statistical hypothesis in this study is as follows:

$\mathrm{H}_{0}$ : there is no effect of the application of the Giving Question and Getting Answer (GQGA) type of cooperative learning model to the learning outcomes of Class IV Class IV Inpres BTN IKIP I Makassar City.

$\mathrm{H}_{\mathrm{a}}$ : there is an effect of the application of the Giving Question and Getting Answer (GQGA) type of cooperative learning model to the learning outcomes of Class IV students of SD Inpres BTN IKIP I Makassar City. 
The statistical hypothesis testing criteria is if the probability is greater than the real level of 0.05 , then $\mathrm{HO}$ is accepted and $\mathrm{Ha}$ is rejected.

\section{Result and Discussion}

The study entitled The Effect of Giving Question and Getting Answer (GQGA) Cooperative Learning Model on the Learning Outcomes of Class IV Students in SD Inpres BTN IKIP I Makassar City aims to find out the description of the application of GQGA cooperative learning models, the description of the learning outcomes of the students, and the effect of applying the Giving Question and Getting Answer (GQGA) type of cooperative learning model to the students' learning outcomes.

Data were obtained through instruments in the form of multiple choice written tests to measure differences in learning outcomes of students in experimental class taught using Giving Question and Getting Answer (GQGA) cooperative learning model and the control class taught without using the Giving Question and Getting Answer (GQGA) cooperative learning model. The subjects in this study were 52 students.

Test for Student learning outcomes have been validated by lecturers who are experts in their fields, namely Amri Amal, S.Pd, M.Pd. who is a PGSD lecturer at the Faculty of Education, Makassar State University and has conducted a field test of students in grade V at SD Inpres BTN IKIP I Makassar City. After being validated, there were 25 items that could be used for research. The valid questions were then used as an instrument to measure student learning outcomes at the beginning before giving treatment (pretest). After the pretest was held, the researcher then applied Giving Question and Getting Answer (GQGA) type of cooperative learning model in science subjects in the experimental class and the control class was taught without using the Giving Question and Getting Answer (GQGA) cooperative learning model.

The study was conducted approximately 2 weeks with 2 meetings for both experimental and control class. At the first meeting, both classes were given a pretest, then the learning process was carried out for 2 meetings and in the last meeting, a posttest was given to find out the differences in learning outcomes.

\section{Description of the Implementation of the Giving Question and Getting Answer (GQGA) Cooperative Learning Model}

Data were obtained through the instrument in the form of an observation sheet the implementation of the Giving Question and Getting Answer (GQGA) learning model which is assessed by the observer based on the assessment indicators. The learning process in the experimental class in Theme 8 Subtheme 1 was held in 2 meetings, namely the first meeting by giving a pretest and giving treatment, and the second meeting giving treatment in the form of applying Giving Question and Getting Answer (GQGA) learning model in the learning process, and posttest was conducted after the learning. Pretest was done to measure students' initial learning outcomes in science subjects before applying a treatment, while the posttest is done to measure students' final learning outcomes in science subjects after applying a treatment.

Observations were made by filling out observation sheets both from teacher's aspect and students' aspects. The application of tGiving Question and Getting Answer (GQGA) learning model on Theme 8 Subtheme 1 Learning 1 and 2 especially in the science subjects in the experimental class had a positive influence on improving student learning outcomes. This is proven by the results of observations that have been made during the learning process. Based 
on observations made in the learning process using Giving Question and Getting Answer (GQGA) cooperative learning model, the results of observations can be seen in the following table:

Table 4. Description of the Implamentation Model

\begin{tabular}{|c|c|c|}
\hline Description & Learning 1 & Learning 2 \\
\hline $\begin{array}{c}\text { The acquisition score/ } \\
\text { Maximal Score }\end{array}$ & $36 / 40$ & $37 / 40$ \\
\hline Percentage & $90 \%$ & $92,5 \%$ \\
\hline Category & Very Effective & Very Effective \\
\hline \multicolumn{2}{|c|}{ Source: Primary Data Processed, 2019 }
\end{tabular}

Based on the data above, it can be concluded that in the learning 1, the learning process was carried out with $90 \%$ achievement rate. The percentage is obtained by dividing the indicator score achieved with a maximum score multiplied by $100 \%$ and is in the very effective category. In the learning 2, the learning process was carried out with $92.5 \%$ achievement rate. The percentage of achievement is in the very effective category. This shows that the implementation of learning using the Giving Question and Getting Answer (GQGA) learning model takes place very effectively because the percentage of categories for each meeting increases.

\section{Overview of Social Studies Learning Outcomes}

Descriptive statistical analysis provides important information about the data obtained in the field and is then presented in a more concise and simple form which ultimately leads to the need for explanation and interpretation. The description of social studies learning outcomes before and after the treatment using GQGA cooperative learning model is as follows;

Table 5. Recapitulation of Research Results

\begin{tabular}{|c|c|c|c|c|}
\hline $\begin{array}{c}\text { Statistical } \\
\text { Variations }\end{array}$ & $\begin{array}{c}\text { Pretest } \\
\text { Experiment }\end{array}$ & Pretest Control & $\begin{array}{c}\text { Posttest } \\
\text { Experiment }\end{array}$ & Posttest Control \\
\hline Lowest Score & 60 & 48 & 72 & 56 \\
\hline Highest Score & 92 & 92 & 100 & 96 \\
\hline Mean & 75,0769 & 73,2308 & 86,1538 & 76,7692 \\
\hline Range & 32 & 44 & 28 & 40 \\
\hline $\begin{array}{c}\text { Standard } \\
\text { Deviation }\end{array}$ & 10,01169 & 13,56557 & 7,9180 & 10,6143 \\
\hline Median & 76 & 74 & 88 & 76 \\
\hline Mode & 76 & 74 & 88 & 76 \\
\hline
\end{tabular}

Source: SPSS version 20.0

If the pretest and posttest scores of the science learning outcomes are grouped in the frequency distribution interval and the percentage of the science learning outcomes categories, then the pretest results of the experimental class and the control class are in the moderate category. The posttest results of the experimental class are in the high category and the control class is in the moderate category. The normality test is carried out with the help of SPSS version 20.0 program using the Kolmogrov-Smirnov test. The data requirements are said to be normally distributed if the significance value or $\mathrm{Sig}_{\text {count }}$ is greater than 0.05 . The following are the results of the normality of the pretest and posttest data in the experimental and control classes. 
Table 7. Pretest Data Normality Test Results and Experiment and Control Posttest Class

\begin{tabular}{|c|c|c|}
\hline Data & Sigcount & Description \\
\hline Pretest Experimental Class & 0,170 & $0,170>0,05=$ normal \\
\hline Pretest Control Class & 0,103 & $0,103>0,05=$ normal \\
\hline Posttest Experimental Class & 0,200 & $0,200>0,05=$ normal \\
\hline Posttest Control Class & 0,200 & $0,200>0,05=$ normal \\
\hline
\end{tabular}

Source: SPSS version 20.0

Based on the table above, the normality test results obtained Sig $_{\text {count }}$ values greater than 0.05 , it can be concluded that the distribution of experimental and control class data is normally distributed. Homogeneity tests were carried out with the help of SPSS version 20.0 program using Levene's Test For Equality of Variances. Data are said to be homogeneous if the significance value or $\mathrm{Sig}_{\text {count }}$ is greater than 0.05 . The following data are the results of the pretest homogeneity of the experimental and control classes and the posttest of the experimental and control classes on the science learning outcomes.

Table 8. Homogeneity Test Results of pretest and posttest in Experiment and Control Class

\begin{tabular}{|c|c|c|}
\hline Data & Sigcount & Description \\
\hline $\begin{array}{c}\text { Pretest } \text { Experimental and Control } \\
\text { Class }\end{array}$ & 0,086 & $0,086>0,05=$ homogen \\
\hline $\begin{array}{c}\text { Posttest } \text { Experimental and Control } \\
\text { Class }\end{array}$ & 0,838 & $0,838>0,05=$ homogen \\
\hline
\end{tabular}

Source: SPSS version 20.0

Based on the table above, the homogeneity test results of the experimental and control class pretest and posttest on science learning outcomes are stated to have homogeneous variance because the significance value is greater than 0.05 . The results of hypothesis test in the pretest and posttest of experimental and control class using the Independent Sample TTest. Data is declared influential if the $\mathrm{Sig}_{2}$-tailed value is smaller than 0.05 . This analysis is used to find out the differences in science learning outcomes between the experimental and control classes.

Table 9. Test Results of Independent Sample T-Test

\begin{tabular}{|c|c|c|}
\hline Data & Sig $_{2 \text {-tailed }}$ & Description \\
\hline $\begin{array}{c}\text { Pretest Experiment and Pretest } \\
\text { Control }\end{array}$ & 0,579 & $0,579>0,05=$ no difference \\
\hline $\begin{array}{c}\text { Posttest } \begin{array}{c}\text { Experiment dan Posttest } \\
\text { Control }\end{array} \\
\text { Corle }\end{array}$ & 0,001 & $\begin{array}{c}0,001<0,05=\text { there is a } \\
\text { difference }\end{array}$ \\
\hline
\end{tabular}

Source: SPSS version 20.0

Based on the table, it can be seen that the probability value of the experimental class and the control class is less than 0.05. This shows that there are significant differences in student learning outcomes between classes taught using Giving Question and Getting Answer (GQGA) cooperative learning model and classes taught without using the Giving Question and Getting Answer (GQGA) cooperative learning model.

Based on the results of the study, an overview of the implementation of GQGA cooperative learning models for science subjects in class IV can be seen on the observation sheet of the implementation of the learning model. At the first meeting, the learning process was carried out with $90 \%$ achievement rate. The percentage of achievement is obtained by 
dividing the indicator score achieved with a maximum score multiplied by $100 \%$ and is in the very effective category. At the second meeting, the learning process was carried out with $92.5 \%$ achievement rate. The percentage of achievement is obtained by dividing the indicator score achieved with a maximum score multiplied by $100 \%$ and is in the very effective category. Teacher activity in implementing GQGA cooperative learning model has increased from a percentage of $90 \%$ to $92.5 \%$ or an increase of $2.5 \%$. This shows that the implementation of GQGA learning model takes place very effectively because the percentage category for each meeting increases. This is in line with the opinion of Zaini (2008) who says that when students learn passively, or only receive from teachers have a tendency to easily forget what has been learned. Through the application of GQGA cooperative learning model, students have a greater ability to remember compared to passive learning resulting to students' mastery of the material becomes better thus improve their learning outcomes.

A descriptive statistical analysis is then performed to obtain student learning outcomes before and after treatment is given. In the descriptive statistical analysis, the average score of students' science learning outcomes in the experimental class before treatment was 75.0769 in the moderate category and after being treated using the Giving Question Getting Answer (GQGA) the average student learning outcomes increased, namely 86.1538 in the high category. While in control class before and after treatment did not increase and remained in the moderate category. This illustrates that there are differences in student learning outcomes between classes that are treated using Giving Question and Getting Answer (GQGA) cooperative learning model. This is in line with Hamdani (2011) who states that learning will take place well and improve its quality when discussing, asking each other questions, and / or explaining to each other. Thus it can be said that the application of Giving Question and Getting Answer (GQGA) type of cooperative learning model has proven to be effective in improving student learning outcomes.

Based on hypothesis test with inferential statistics shows that there is a significant effect in students' learning outcomes after the use of GQGA in the learning process. The results of hypothesis test are carried out in two ways, namely comparing $t_{\text {table }}$ and $t_{\text {count }}$ and comparing the probability values. Statistical results use calculations with the help of the SPSS Version 20 program for Independent Sample T Test. The value of $t_{\text {table }}$ is obtained with df $(50)=2.008$ while the t-test results of students' answers are $3,614, \mathrm{t}_{\text {count }}(3,614)>\mathrm{t}$-table $(2,008)$ so that $\mathrm{H}_{0}$ is rejected and $\mathrm{H}_{\mathrm{a}}$ is accepted regardless being positive (+) or negative (-). Whereas by comparing the probability values, the posttest significance value of the experimental class was 0.001 . Comparison of the probability value of $0.001<0.05$ means that $\mathrm{H}_{0}$ is rejected and $\mathrm{H}_{\mathrm{a}}$ is accepted. So it can be concluded that there is an effect of GQGA learning model on students' science learning outcomes in class IV SD Inpres BTN IKIP I Makassar City. This is reinforced by the results of research conducted by several previous researchers, including the research results of Gaus Setyawan Erdas (2015) on the Application of Cooperative Learning Models Giving Question and Getting Answer Types in Improving Activities for Student Learning Outcomes in ICT subject Class VII Middle School 1 Bekri Academic Year $2015 / 2016$. In addition, this research is also supported by the research conducted by Ning Tias Prima Wilinda (2013) The Effectiveness of Giving Question and Getting Answer Strategies for Learning Outcomes of Natural Resources Students in Class IV State Elementary School 06 Petarukan Pemalang. Therefore, it can be said that the application of Giving Question and Getting Answer (GQGA) cooperative learning model has a significant influence. 


\section{Conclusion and Suggestion}

The learning process using Giving Question and Getting Answer (GQGA) learning model in the experimental class takes place effectively because the percentage category for each meeting increases according to the steps in applying the learning model. Student learning outcomes in the experimental class improved more than student learning outcomes in the control class. This is evidenced by the average student learning outcomes before treatment were in the moderate category and after treatment were in the high category. There is an influence on the application of Giving Question and Getting Answer (GQGA) learning model. This is evidenced by the significant differences between the experimental classes using the learning model, i.e the learning outcomes were in the high category and control class results without using GQGA learning model are in the moderate category.

It is suggested that the Head of School gives appreciation to teachers who develop learning models to improve student learning outcomes. For teachers, GQGA learning model can be an alternative to improve students' science learning outcomes. For further research, it can be used as a reference in conducting research to improve student learning outcomes in science subjects.

\section{Reference}

Arikunto, S. 2013. Dasar-Dasar Evaluasi Pendidikan. Jakarta: Bumi Aksara.

Erdas, Gaus Setyawan. 2015. Penerapan Model Pembelajaran Kooperatif Learning Tipe Giving Question and Getting Answer dalam meningkatkan keaktifan untuk hasil belajar Siswa pada Mata Pelajaran TIK Kelas VII SMP N 1 Bekri Tahun Ajaran 2015/2016. Skripsi. Semarang: Universitas Negeri Semarang.

Hamdani. 2011. Strategi Belajar Mengajar. Bandung: Pustaka Setia.

Hisbullah, \&Selvi, N. 2018. Pembelajaran Ilmu Pengetahuan Alam Di Sekolah Dasar. Makassar: Aksara Timur.

Isjoni. 2012. Cooperative Learning. Bandung: Alfabeta.

Mariyaningsih, N \& Hidayat, M. 2018. Bukan Kelas Biasa: Teori Dan Praktik Berbagai Model Pembelajaran Menerapkan Inovasi Pembelajaran Di Kelas-Kelas Inspiratif. Surakarta: Kekata Publisher.

Rusman. 2017. Belajar Dan Pembelajaran Berorientasi Standar Proses Pendidikan. Jakarta: PT Kharisma Putra Utama.

Tim Dosen. 2017. Ragam Model Pembelajaran Di Sekolah Dasar (Edisi Ke-2). Sumedang: UPI Sumedang Press.

Zaini, Hisyam. 2008. Strategi Pembelajaran Aktif. Yogyakarta: Pustaka Insan Madani.

Undang-Undang Nomor 20 Tahun 2003 Tentang Sistem Pendidikan Nasional. Jakarta: Depdiknas.

Wilinda, Ning T. P. 2013. Keefektifan Strategi Giving Question and Getting Answer Terhadap Hasil Belajar Sumber Daya Alam Siswa Kelas IV Sekolah Dasar Negeri 06 Petarukan Pemalang. Skripsi. Semarang: Universitas Negeri Semarang. 